\title{
Effects of Carrier Materials on Anaerobic Hydrogen Production by Continuous Mixed Immobilized Sludge Reactors
}

\author{
Qiaoyan $\mathrm{Li}^{1}{ }^{1,2}$, Yikun $\mathrm{CaO}^{3}$, Yongfeng $\mathrm{Li}^{1 *}$ \\ 1 School of Forestry, Northeast Forestry University, 150060 Harbin, 26 Hexing road, China \\ 2 School of Environment and Planning, Liaocheng University, 252000 Liaocheng, 1 Hunan road, China \\ ${ }^{3}$ Baoshan Environmental Protection Agency, 201906 Shanghai, 2 Mishan Road, China \\ * Corresponding author, e-mail: dr_lyf@163.com
}

Received: 22 January 2019, Accepted: 07 June 2019, Published online: 07 August 2020

\begin{abstract}
To enhance hydrogen production rate and increase substrate utilization efficiency of anaerobic fermentation, three carrier materials, Granular Activated Carbon (GAC), Zeolite Molecular Sieve (ZMS) and Biological Ceramic Ring (BCR), were used as carrier materials in Continuous Mixed Immobilized Sludge Reactors (CMISRs). The effects of carrier materials and substrate organic loading rate (OLR, $\mathrm{OLR}=12,24,36,48 \mathrm{~kg} / \mathrm{m}^{3} / \mathrm{d}$ ) on biohydrogen production were investigate, respectively. The highest HPRs of ZMS, GAC and BCR were achieved under the OLR of $36 \mathrm{~kg} \mathrm{COD} / \mathrm{m}^{3} / \mathrm{d}$, and were 2.01, 1.81, and $2.86 \mathrm{~L} / \mathrm{L} / \mathrm{d}$, respectively. The highest COD removal efficiencies of ZMS, GAC and BCR were $38.95 \%\left(\mathrm{OLR}=24 \mathrm{~kg} C O D / \mathrm{m}^{3} / \mathrm{d}\right), 36.47 \%\left(\mathrm{OLR}=36 \mathrm{~kg} \mathrm{COD} / \mathrm{m}^{3} / \mathrm{d}\right)$, and $41.03 \%\left(\mathrm{OLR}=36 \mathrm{~kg}\right.$ COD $\left./ \mathrm{m}^{3} / \mathrm{d}\right)$, respectively. The best substrate degradation rate of ZMS, GAC and BCR were $40.33 \%\left(O L R=24 \mathrm{~kg} \mathrm{COD} / \mathrm{m}^{3} / \mathrm{d}\right), 38.30 \%\left(\mathrm{OLR}=24 \mathrm{~kg} C O D / \mathrm{m}^{3} / \mathrm{d}\right) \mathrm{and}$ $45.60 \%\left(\mathrm{OLR}=12 \mathrm{~kg} \mathrm{COD} / \mathrm{m}^{3} / \mathrm{d}\right)$. The results indicated that biological ceramic ring get better hydrogen production and wastewater treatment performance as sludge carrier material for hydrogen production in immobilized bioprocesses.
\end{abstract}

Keywords

anaerobic sludge, carrier material, ethanol-type fermentation, immobilized techniques

\section{Introduction}

The production of clean energy has become an urgent research area because severe global environmental problems (global warming, acid rain, ozone holes, etc.) appear to be caused by the combustion of fossil fuels (coal and oil) [1]. Hydrogen has a high calorific value of $286 \mathrm{~kJ} / \mathrm{mol}$, and the combustion product is water, which is environmentally friendly. Therefore, hydrogen can be used as an ideal energy to substitute fossil fuels [2]. Traditional hydrogen production methods have relied on fossil fuels accompanied by the emission of greenhouse gases [3, 4]. Biohydrogen production from activated sludge through anaerobic fermentation has unique advantages of high ecological adaptability, simple reaction conditions and low nutrient requirements $[5,6]$, which have been extensively researched worldwide. The Continuous Stirred Tank Reactors (CSTR) is one of the most commonly used anaerobic reactors both in engineering applications and in experimental studies, it is equipped with a magnetic stirrer, which can keep the microorganisms of the anaerobic sludge in suspension by adjusting the stirring rate, and the biochemical reaction rate increases with the increase in the impeller rotation rate $[7,8]$. However, the suspended microorganisms are influenced by the increase in the hydraulic load applied by the rotating impeller; therefore, sludge is easily washed out [9]. The loss of microbial biomass can reduce the fermentation efficiency and hydrogen production rate of the fermentation system. Sufficient biomass is needed to maintain a high hydrogen production rate [10, 11]. A Continuous Mixed Immobilized Sludge Reactor (CMISR) was developed used cell immobilization technology and could effectively keep high biomass concentration.

Cell immobilization techniques can be used to increase the biomass concentration for both the mixed and pure cultures [12-14]. Lutpi et al. [15] immobilized anaerobic sludge from palm oil mill effluent on GAC and used sucrose as a substrate in repeated batches. The maximum HPR was found to be $2.7 \mathrm{mmol} \mathrm{H}_{2} / \mathrm{L} / \mathrm{h}$, and the hydrogen yield peaked at $2.8 \mathrm{~mol} \mathrm{H}_{2}$ (mol hexose consumed $)^{-1}$ at an HRT of 12 h. Mohan et al. (2008) [16] investigated 
anaerobic sludge immobilized on mesoporous material [SBA-15(mesoporous)] and activated carbon using chemical wastewater as a substrate and obtained a $\mathrm{H}_{2}$ production rate of $7.29 \mathrm{~mol} / \mathrm{kg} \mathrm{COD} / \mathrm{d}$ at an OLR of $0.83 \mathrm{~kg} \mathrm{COD} / \mathrm{m}^{3} / \mathrm{d}$.

The carrier materials for immobilization can be synthetic polymers, such as calcium alginate and polyvinyl alcohol, or naturally available materials, such as lignocellulosic materials from agricultural residues [17]. The selection of the immobilized materials should be pliable to release the generated hydrogen, have optimum porosity and be economic when it comes to large scale procurement. Granular Activated Carbon (GAC), Zeolite Molecular Sieve (ZMS) and Biological Ceramic Ring (BCR) are used as the immobilized materials in CMISR. Activated carbon has undoubtedly been the most popular and widely used adsorbent in wastewater treatment applications throughout the world [18], and as one of the activated carbon, GAC has good adsorption efficiency, but it has the relatively high cost which led to the researches on alternative low-cost immobilized materials [19]. ZMS has a high ion exchange rate and outstanding resistance to erosion by acid, alkali and salt [20]. BCR is a novel product that has been widely used in the water-purification industry in the last few years owing to its high-density microspores and surface area up to $1650 \mathrm{~m}^{2} / \mathrm{g}$, which is suitable for the attachment and growth of microorganisms [21]. In addition, BCR has good chemical stability, and it can be washed and reused repeatedly, which causing BCR has greater potential in large-scale systems [22].

The BCR and ZMS are less studied in hydrogen production and the studies on comparison of immobilized materials in CMISR for hydrogen production is limited. Thus, the study of additional available carrier materials is needed to achieve a higher substrate conversion as well as higher HPR and hydrogen yields. In this experiment, GAC, ZMS and BCR were employed as carrier materials in an anaerobic hydrogen production system. The hydrogen production capacity, the system stability and the energy recovery efficiency were compared to determine the optimal carrier material. The results of this experimental study can provide a reference for fermentative hydrogen production experiments.

\section{Materials and methods}

\subsection{Physical properties of carrier materials}

In this study, three different materials, ZMS, GAC and $\mathrm{BCR}$, were selected as carrier materials in a CMISR hydrogen production system. The main physical properties of the three materials are listed in Table 1.
Table 1 Main physical characteristics of ZMS, GAC and BCR

\begin{tabular}{lccc}
\hline Carrier material & $\begin{array}{c}\text { Diameter } \\
(\mathrm{mm})\end{array}$ & $\begin{array}{c}\text { Density } \\
(\mathrm{g} / \mathrm{L})\end{array}$ & $\begin{array}{c}\text { Specific surface area } \\
\left(\mathrm{m}^{2} / \mathrm{g}\right)\end{array}$ \\
\hline ZMS & $4-6$ & $1920-2800$ & 1100 \\
GAC & $1.5-2$ & 1420 & 950 \\
BCR & $10 \times 10$ & $2500-3600$ & 1650 \\
\hline
\end{tabular}

The three carrier materials have different physical characteristics; ZMS has a high ion exchange rate and outstanding resistance to erosion by acid, alkali and salt. GAC is widely used in both wastewater and waste gas treatment due to its porous structure providing a large internal surface area and its low cost causing GAC has greater potential in large-scale systems. In addition, BCR is a novel product that has been widely used in the water-purification industry in the last few years owing to its high-density microspores and surface area up to $1650 \mathrm{~m}^{2} / \mathrm{g}$, which is suitable for the attachment and growth of microorganisms. In addition, BCR has good chemical stability, and it can be washed and reused repeatedly [23].

\subsection{Feed composition and inoculated sludge}

The molasses wastewater was collected from the local sugar refinery, and the wastewater composition is shown in Table 2. The fermentation substrate was maintained a COD:N:P ratio of 200-800:5:1 by diluting molasses wastewater and adding $\mathrm{NH}_{4} \mathrm{Cl}$ and $\mathrm{KH}_{2} \mathrm{PO}_{4}$, and the influential also added by $\mathrm{NaHCO}_{3}, \mathrm{MgCl} \cdot 6 \mathrm{H}_{2} \mathrm{O}, \mathrm{Na}_{2} \mathrm{MoO}_{4} \cdot 4 \mathrm{H}_{2} \mathrm{O}$, $\mathrm{CaCl}_{2} \cdot 2 \mathrm{H}_{2} \mathrm{O}, \mathrm{MnCl}_{2} \cdot 6 \mathrm{H}_{2} \mathrm{O}$ and $\mathrm{FeCl}_{2} \cdot 4 \mathrm{H}_{2} \mathrm{O}$.

The anaerobic seed sludge used in this study was obtained from the secondary sedimentation tank of a local municipal wastewater treatment plant (Harbin, China). The sludge was sieved through a mesh with a diameter of $0.5 \mathrm{~mm}$ to eliminate large particulates. Afterwards, the raw sludge was aerated intermittently to inhibit the methanogen biological activity. After 30 days, the MLVSS and VSS/SS of the sludge were $15.77 \mathrm{~g} / \mathrm{L}$ and $68 \%$, respectively. ZMS, GAC and BCR were added to immobilize the anaerobic sludge through surface attachment,

Table 2 The composition of molasses wastewater

\begin{tabular}{lccc}
\hline Composition & Percentage (\%) & Composition & Percentage (\%) \\
\hline Dry matter & $75-85$ & $\mathrm{MgO}$ & $0.01-0.1$ \\
Total suger & $48-58$ & $\mathrm{~K}_{2} \mathrm{O}$ & $2.2-4.5$ \\
TOC & $28-34$ & $\mathrm{SiO}_{2}$ & $0.1-0.5$ \\
$\mathrm{TKN}$ & $0.2-2.8$ & $\mathrm{Al}_{2} \mathrm{O}_{3}$ & $0.05-0.06$ \\
$\mathrm{P}_{2} \mathrm{O}_{5}$ & $0.02-0.07$ & $\mathrm{Fe}_{2} \mathrm{O}_{3}$ & $0.001-0.02$ \\
$\mathrm{CaO}$ & $0.15-0.8$ & $\mathrm{Ash}$ & $4-8$ \\
\hline
\end{tabular}


the addition ratio of reactor effective volume $(\mathrm{mL}$, CMISR) to materials weight (g, carrier material) was 20:1, then the sludges were aerated for $24 \mathrm{~h}$ before inoculated into the CMISR, respectively.

\subsection{Continuous immobilized sludge reactor}

Three continuous CMISR hydrogen production systems (Fig. 1) with the effective volume of $6.0 \mathrm{~L}$ were used in this study. Each CMISR was equipped with a solid - liquid gas three-phase separation device and a magnetic stirrer; and the stirring rate was controlled at $50 \mathrm{rpm}$ to control the rotation speed of the inner fermentation substrate. A temperature sensor was installed inside the CMISR and was connected with a temperature control device to maintain an internal temperature of $35 \pm 1{ }^{\circ} \mathrm{C}$, maintaining the optimum temperature environment for microorganisms in the anaerobic activated sludge.

The influent flow rate was controlled by a feed pump to maintain the Hydraulic Retention Time (HRT) at $6 \mathrm{~h}$ in this system. Each CMISR was started up with the OLR of $12 \mathrm{~kg} \mathrm{COD} / \mathrm{m}^{3} / \mathrm{d}$ using molasses wastewater as the fermentation substrate. Each CMISR was operated in batch mode until gas was produced. Reactors were then switched to continuous mode (HRT $=6 \mathrm{~h}$ ) with the OLR of $12 \mathrm{~kg} / \mathrm{m}^{3} / \mathrm{d}$ until steady state conditions were obtained. Steady state conditions were based on the constant products with a variation of less than $10 \%$. Each CMISR was sampled at the fixed OLR over at least 10 days. The OLR was then increased to the next level $\left(24,36\right.$ and $\left.48 \mathrm{~kg} \mathrm{COD} / \mathrm{m}^{3} / \mathrm{d}\right)$ and the reactor was operated until steady state conditions were achieved as noted above. All the samples obtained from this study were analyzed in triplicate.

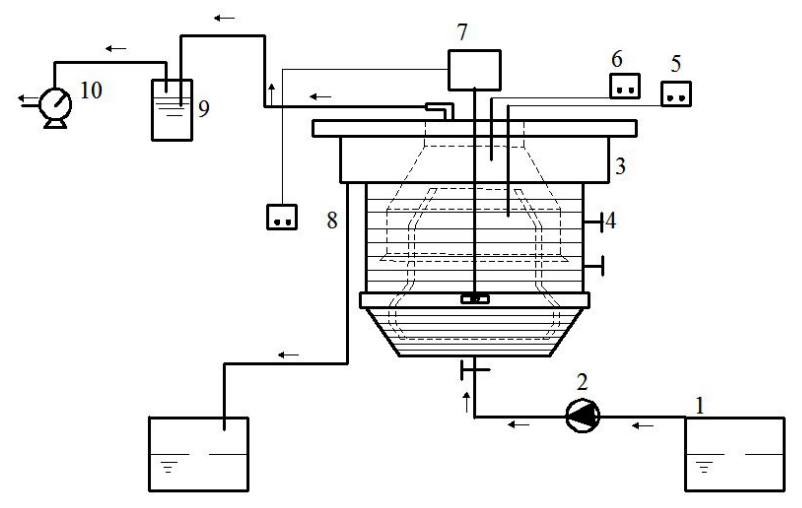

Fig. 1 Structure diagram of CMISR

1) Influent box, 2) Peristaltic pump, 3) CMISR, 4) Sample outlet, 5) Temperature sensor, 6) Water lock, 7) Magnetic stirrer, 8) Effluent box, 9) Water lock, 10) Wet gas meter.

\subsection{Analytical methods}

Biogas produced from the CMISR was collected and measured daily at a room temperature using a wet gas meter (Model LML-1, Changchun Filter, Changchun, China). The hydrogen content was analyzed by a gas chromatograph (SC-7, Shandong Lunan Instrument Factory), which was equipped with a thermal conductivity detector (TCD) and a stainless-steel column $(2 \mathrm{~m} \times 5 \mathrm{~mm})$ filled with Porapak Q (50-80 mesh). Nitrogen was used as the carrier gas at a flow rate of $40 \mathrm{~mL} / \mathrm{min}$. VFAs (HAc, HPr, and $\mathrm{HBu}$ ) and ethanol in the fermentation solution were analyzed by a gas chromatograph (GC 112, Shanghai Anal. Inst. Co.). The gas chromatograph was equipped with a flame ionization detector (FID), and a $2 \mathrm{~m}$ stainless-steel column was packed with the GDX-103 (60-80 mesh) support material. The temperatures of the injection port, oven, and detector were $220{ }^{\circ} \mathrm{C}, 190{ }^{\circ} \mathrm{C}$, and $220^{\circ} \mathrm{C}$, respectively. Nitrogen was used as the carrier gas at a flow rate of $30 \mathrm{~mL} / \mathrm{min}$ [24]. The COD, $\mathrm{pH}$, Oxidation-Reduction Potential (ORP) and biogas yield were monitored daily according to standard methods [25].

\subsection{Substrate degradation rate}

Substrate degradation rate is defined as the measure of the percentage of organic matter anaerobically degraded and can be calculated from the detected SMP, the influent COD concentration and the daily influent volume of molasses wastewater according to Eq. (1):

$$
\begin{aligned}
& \mathrm{AD}=\frac{\mathrm{EtOH} \times 2.09+\mathrm{HAc} \times 1.07+\mathrm{HPr} \times 1.51+\mathrm{HBu} \times 1.82}{Q \times \mathrm{COD}_{i n f}} \\
& \times 100 \%
\end{aligned}
$$

where $\mathrm{EtOH}, \mathrm{HAc}, \mathrm{HPr}$ and $\mathrm{HBu}$ represent the concentration of ethanol, acetate, propionate and butyrate $(\mathrm{mg} / \mathrm{L})$, respectively; 2.09, 1.07, 1.51 and 1.82 represent the equivalent COD of ethanol, acetate, propionate and butyrate, respectively. $Q$ represents the daily influent volume of molasses wastewater $(\mathrm{L} / \mathrm{d})$. $\mathrm{COD}_{\text {inf }}$ represents the $\mathrm{COD}$ concentration of influent molasses wastewater $(\mathrm{mg} / \mathrm{L})$.

\section{Results and discussion}

\subsection{Hydrogen production performance}

To investigate the effects of three carrier materials, ZMS, GAC and BCR, on the hydrogen production from anaerobic fermentation in a CMISR, the biogas production rate, hydrogen content and Hydrogen Production Rate (HPR) of 4 different OLRs $\left(12,24,36\right.$, and $\left.48 \mathrm{~kg} \mathrm{COD} / \mathrm{m}^{3} / \mathrm{d}\right)$ 
were monitored. As shown in Table 3 and Fig. 2, the carrier materials and OLRs had significant effects on the HPR and hydrogen content. The CMISR system continuously released hydrogen from the $3^{\text {rd }}$ day of sludge inoculation, and no methane was detected during the whole period. The intermittent aeration of raw sludge can inhibit the activity of methanogens while maintaining metabolism of hydrogenogens. Under a low OLR $\left(12 \mathrm{~kg} \mathrm{COD} / \mathrm{m}^{3} / \mathrm{d}\right)$, the HPRs of ZMS, GAC and BCR were 0.54, 0.55, and $0.61 \mathrm{~L} / \mathrm{L} / \mathrm{d}$, respectively. Along with the increased OLR, the HPRs of the three carrier materials showed great differences. At an OLR of $24 \mathrm{~kg} \mathrm{COD} / \mathrm{m}^{3} / \mathrm{d}$, the HPR of ZMS, GAC and BCR was1.45, 1.04 and $1.78 \mathrm{~L} / \mathrm{L} / \mathrm{d}$, respectively; HPR of BCR was 1.71 times that of GAC and 1.22 times that of ZMS. In addition, at an OLR of $36 \mathrm{~kg} \mathrm{COD} / \mathrm{m}^{3} / \mathrm{d}$, the HPRs of ZMS, GAC and BCR reached the highest; the HPR of BCR was $2.86 \mathrm{~L} / \mathrm{L} / \mathrm{d}$, and it was 1.46 times that of GAC $(2.01 \mathrm{~L} / \mathrm{L} / \mathrm{d})$ and 1.59 times that of ZMS $(1.81 \mathrm{~L} / \mathrm{L} / \mathrm{d})$. Among the immobilization materials, BCR resulted in higher hydrogen production than ZMS and GAC, possibly because of the higher biomass attachment capacity of ceramic ring material resulting in higher biomass inventory [23]. And an OLR of $36 \mathrm{~kg} \mathrm{COD} / \mathrm{m}^{3} / \mathrm{d}$ was the optimum OLR condition for the continuous production of hydrogen from molasses wastewater in CMISR.

Table 3 HPRs of immobilized CMISR system

\begin{tabular}{|c|c|c|c|c|c|}
\hline $\begin{array}{l}\text { HPR } \\
\\
(\mathrm{L} / \mathrm{L} / \mathrm{d}) \\
\text { OLR } \\
\left(\mathrm{kg} \mathrm{COD} / \mathrm{m}^{3} / \mathrm{d}\right)\end{array}$ & ZMS & GAC & BCR & $\begin{array}{l}\text { ANOVA } \\
\text { summary } \\
-P \text { value }\end{array}$ & $\begin{array}{c}\text { Significant } \\
\text { diff. among } \\
\text { means } \\
(P<0.05)\end{array}$ \\
\hline 12 & 0.54 & 0.55 & 0.61 & 0.018 & Yes \\
\hline 24 & 1.45 & 1.04 & 1.78 & $<0.0001$ & Yes \\
\hline 36 & 2.01 & 1.81 & 2.86 & 0.0362 & Yes \\
\hline 48 & 1.26 & 0.61 & 2.25 & $<0.0001$ & Yes \\
\hline
\end{tabular}

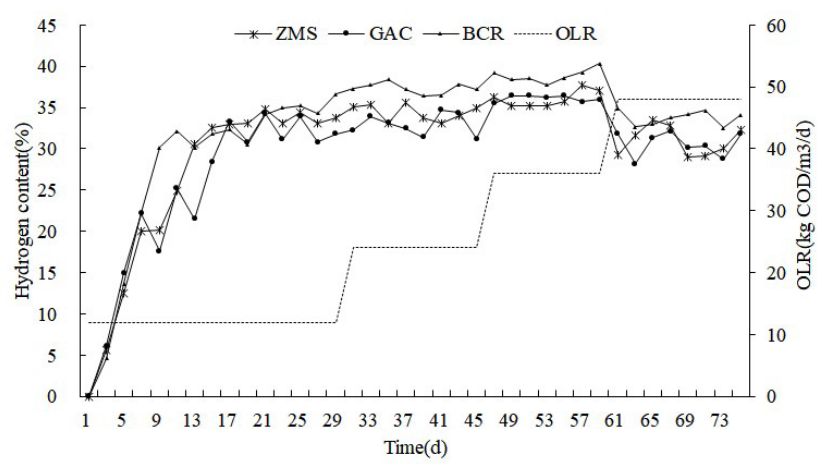

Fig. 2 Hydrogen content of immobilized CMISR system
The performance of other immobilized sludge hydrogenproduction systems using natural or synthetic support carriers got the maximum HPR in range of 0.07414.64 L/L/d (Table 4 [15], [23], [26]-[29]). In this study, the best HPR of $2.86 \mathrm{~L} / \mathrm{L} / \mathrm{d}$ was obtained at OLR of $40 \mathrm{~kg} \mathrm{COD} / \mathrm{m}^{3} / \mathrm{d}$. The CMISR would be more feasible in practical applications, because the substrate (molasses wastewater) used in this study was more complex and available compared to other studies.

\subsection{Fermentation type and substrate degradation rate}

During the fermentation progress of molasses, various kinds of Soluble Metabolite Products (SMP) are generated along with the hydrogen production, and the main SMPs are found to be ethanol, acetate, butyrate and propionate $[30,31]$. Metabolite composition is a very important factor effecting hydrogen production directly.

Thorough the study of the concentrations and compositions of SMPs, the fermentation pathway can be concluded. The fermentation pathway can be concluded into 5 types, butyric acid fermentation, lactic acid fermentation, propionic acid fermentation, ethanol fermentation and mixed acid fermentation, of which ethanol-type pathway is a better and more stable metabolic pathway for hydrogen production [32]. Ethanol-type fermentation is characterized by the sum content of the acetic acid and ethanol accounts for over $70 \%$ of the total metabolites. Fig. 3 lists the components and content of the Soluble Metabolites Product (SMP) hydrolyzed from molasses wastewater by hydrolytic fermentation bacteria using different carrier materials. As shown in Fig. 3, the SMPs content had positive correlation with the OLRs, the SMP content under $12 \mathrm{~kg} \mathrm{COD} / \mathrm{m}^{3} / \mathrm{d}$ OLR in ZMS, GAC and BCR immobilized CMISR were 734.04, 730.42 and $1074.25 \mathrm{mg} / \mathrm{L}$, respectively, and SMPs increased to $2079.11,2075.93,2281.64 \mathrm{mg} / \mathrm{L}$ under $48 \mathrm{~kg} \mathrm{COD} / \mathrm{m}^{3} / \mathrm{d}$ OLR. According to the definition of ethanol-type fermentation of Ren et al. [33], the sum percentage of ethanol and acetate accounted for over $70 \%$ of the SMPs. As shown in Fig. 3, the fermentation types were maintained at ethanol-type under the OLR from 12 to $48 \mathrm{~kg} \mathrm{COD} / \mathrm{m}^{3} / \mathrm{d}$.

Substrate degradation rate is defined as the measure of the percentage of organic matter anaerobically degraded and can be calculated from the detected SMP, the influent COD concentration and the daily influent volume of molasses wastewater according to Eq. (1).

The maximum substrate degradation rates of $\mathrm{ZMS}$, GAC and BCR were $40.33 \%\left(\mathrm{OLR}=24 \mathrm{~kg} \mathrm{COD} / \mathrm{m}^{3} / \mathrm{d}\right)$, 
Table 4 Comparison of hydrogen production rate obtained from various immobilization materials

\begin{tabular}{|c|c|c|c|c|c|c|c|}
\hline Inoculum & Reactor & Carrier materials & Substrate & $\begin{array}{l}\text { HRT } \\
\text { (h) }\end{array}$ & $\begin{array}{c}\text { Temperature } \\
\left({ }^{\circ} \mathrm{C}\right)\end{array}$ & $\operatorname{HPP}(\mathrm{L} / \mathrm{L} / \mathrm{d})$ & Reference \\
\hline Sewage sludge & $\begin{array}{c}\text { Continuous } \\
\text { CSABR, AGSBR }\end{array}$ & $\begin{array}{c}\text { Powdered } \\
\text { activated carbon }\end{array}$ & Glucose & 6.0 & - & 14.64 & Wu et al. [26] \\
\hline $\begin{array}{l}\text { House hold solid } \\
\text { waste }\end{array}$ & $\begin{array}{l}\text { Up-flow biofilm } \\
\text { reactor }\end{array}$ & Plastic carrier & Glucose & - & 70 & 0.074 & Zheng et al. [27] \\
\hline Anaerobic sludge & $\begin{array}{l}\text { Up-flow anaerobic } \\
\text { reactor }\end{array}$ & Ceramic rings & Sucrose & 1.5 & 55 & 2.98 & Keskin et al. [23] \\
\hline Anaerobic sludge & $\begin{array}{l}\text { An fluidised bed } \\
\text { column reactor } \\
\text { (FBCR })\end{array}$ & GAC & Palm oil mill & 12 & 60 & 1.45 & Lutpi et al. [15] \\
\hline Anaerobic sludge & CSTR & - & $\begin{array}{c}\text { Molasses } \\
\text { wastewater }\end{array}$ & 6.0 & 35 & 1.72 & Li et al. [28] \\
\hline Anaerobic sludge & CSTR & - & molasses & 24 & & 1.43 & Yun and Cho [29] \\
\hline Anaerobic sludge & CMISR & BCR & $\begin{array}{c}\text { Molasses } \\
\text { wastewater }\end{array}$ & 6 & 35 & 2.86 & This study \\
\hline
\end{tabular}

$38.30 \%\left(\mathrm{OLR}=24 \mathrm{~kg} \mathrm{COD} / \mathrm{m}^{3} / \mathrm{d}\right)$ and $45.60 \%$ $\left(\mathrm{OLR}=12 \mathrm{~kg} \mathrm{COD} / \mathrm{m}^{3} / \mathrm{d}\right)$, respectively (Fig. 4). In lower OLRs $\left(12,24\right.$ and $\left.36 \mathrm{~kg} \mathrm{COD} / \mathrm{m}^{3} / \mathrm{d}\right)$, the substrate degradation rate in the CMISR was maintained at over $30 \%$, and BCR showed better substrate degradation rate than ZMS and GAC, when the OLR increased to $48 \mathrm{~kg} \mathrm{COD} / \mathrm{m}^{3} / \mathrm{d}$, the substrate degradation rate of ZMS and GAC decreased to $26.97 \%$ and $27.00 \%$, respectively, which are consistent with the results of the COD removal efficiencies. The good performance of BCR can be explained because of its specific surface area $\left(1650 \mathrm{~m}^{2} / \mathrm{g}\right)$ and porosity which provides additional surface to attachment generate the biofilm for the bacteria biomass [34], which have a high tendency in binding capacity which mostly for organic matter, and therefore provide an environment that is rich in nutrients and hence promoting the microbial adhesion [35].

\subsection{Performance of the CMISR system}

The fermentation substrate in this experiment was molasses wastewater, which was the by-product of beet sugar production. The main components of molasses were sucrose, glucose and fructose, and the organic compounds can be degraded by microorganisms. The COD removal efficiency (Fig. 5) was greater than $70 \%$ on the first and second day after start-up, which can be owing to the carrier materials, which had strong adsorption ability of organics, owing to their large internal surface area and abundance of pores. The COD removal efficiency of the three carrier materials on the first day was $\operatorname{GAC}(82.32 \%)>\operatorname{BCR}(72.57 \%)>$ ZMS $(63.83 \%)$, which was mainly due to the carrier materials were supplied at the same weight, and GAC has the mines density of $1420 \mathrm{~g} / \mathrm{L}$, which made it had the largest volume and specific surface area from a combination of the inner surface area and large pore volume; therefore, and GAC can adsorb more non-polar and weakly polar organic molecules [36] at the start-up phase. The acclimated activated sludge contained a large amount of dissolved oxygen from the intermittent aeration phase, so the relatively high COD removal rate was caused by the complete oxidation of the organic compounds by the microorganisms.

As the carrier materials approached a saturated adsorption state and the activity of the aerobic bacteria were inhibited by the anaerobic environment, the COD removal efficiency decreased to $10 \%$. As the facultative anaerobic bacteria and anaerobic bacteria gradually adapted to the anaerobic environment, the absorption and conversion efficiency of organic matter in molasses wastewater gradually increased with the rapid growth and succession of microorganisms. The highest COD removal efficiencies of ZMS, GAC and BCR were $38.95 \%\left(\mathrm{OLR}=24 \mathrm{~kg} \mathrm{COD} / \mathrm{m}^{3} / \mathrm{d}\right)$, $36.47 \%\left(\mathrm{OLR}=36 \mathrm{~kg} \mathrm{COD} / \mathrm{m}^{3} / \mathrm{d}\right)$, and $41.03 \%$ $\left(\mathrm{OLR}=36 \mathrm{~kg} \quad \mathrm{COD} / \mathrm{m}^{3} / \mathrm{d}\right)$, respectively. Under OLR $=48 \mathrm{~kg} \mathrm{COD} / \mathrm{m}^{3} / \mathrm{d}$, the inner $\mathrm{pH}$ was $3.91( \pm 0.43)$, the COD removal efficiency of BCR can be maintained at $29.95 \%$, and this is mainly because the BCR has good acid resistance [21, 22]. The physical properties, such as surface potential, do not change in acidic environments and do not affect the biofilm properties on the surface and microbial activity. The COD removal efficiency of ZMS and GAC decreased rapidly, and the low $\mathrm{pH}$ environment caused both the surface of the carrier material and the organic wastewater to be positively charged. An electrostatic repulsion was generated, weakening the complexation between the carrier material and the organic wastewater, 

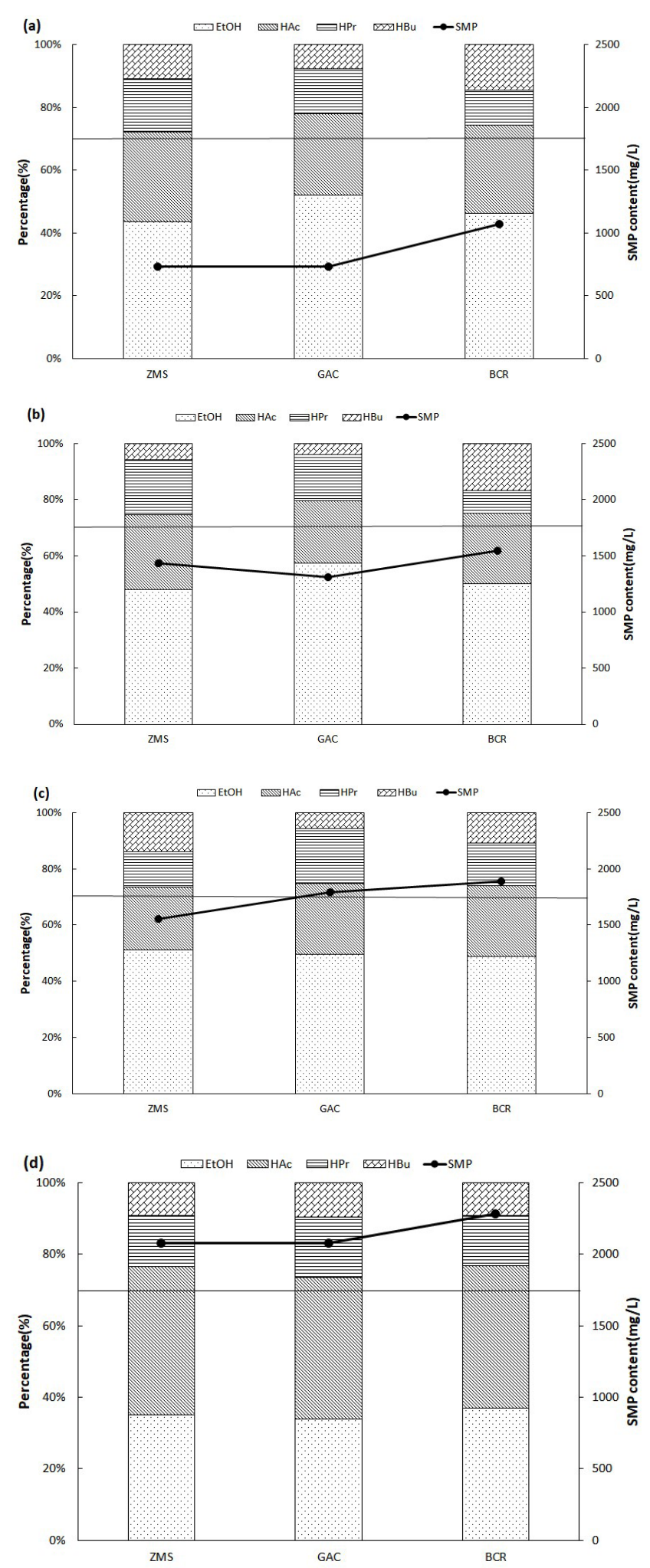

Fig. 3 Concentrations and compositions of SMPs (a) $\mathrm{OLR}=12 \mathrm{~kg} \mathrm{COD} / \mathrm{m}^{3} / \mathrm{d}$, (b) OLR $=24 \mathrm{~kg} \mathrm{COD} / \mathrm{m}^{3} / \mathrm{d}$, (c) $\mathrm{OLR}=36 \mathrm{~kg} \mathrm{COD} / \mathrm{m}^{3} / \mathrm{d}$, (d) OLR $=48 \mathrm{~kg} \mathrm{COD} / \mathrm{m}^{3} / \mathrm{d}$.

thus, inhibiting the carrier material absorptivity and metabolic activity of the microorganisms in the biofilms [37].

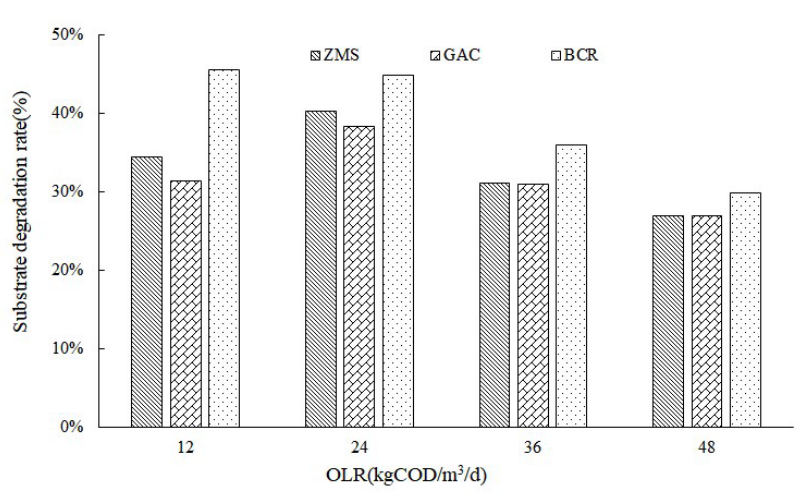

Fig. 4 Substrate degradation rate of substrate degradation rate

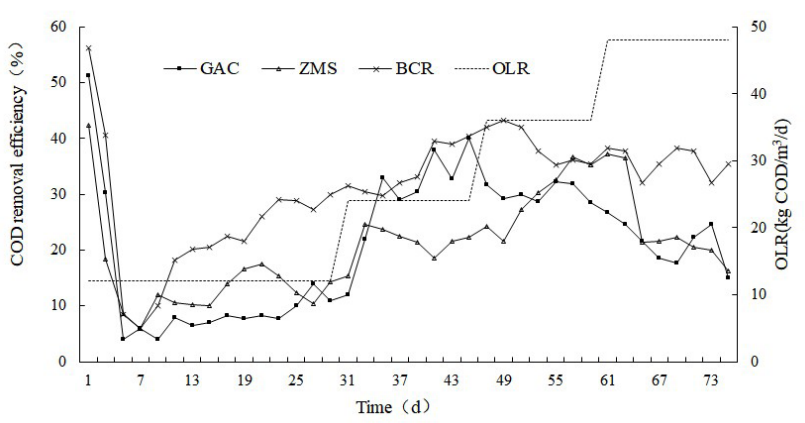

Fig. 5 COD removal efficiency of immobilized CMISR system

Hydrogenogens are very sensitive to the change in $\mathrm{pH}$, and the changed $\mathrm{pH}$ would affect the growth and reproduction rate and the microbial community structure in both the start-up and operation phases [38]. A low $\mathrm{pH}(\mathrm{pH}<3.2)$ would cause the hydrogen-producing bacteria to deviate from the normal physiological conditions, thereby reducing the level of metabolism [39]. To maintain the normal activity of hydrogen-producing bacteria and inhibit the metabolism of methanogens, the $\mathrm{pH}$ of the CMISR can be controlled at approximately 4.2 to maintain ethanol-type fermentation accordingly [40].

As shown in Fig. 6, on the first day, the $\mathrm{pH}$ of ZMS, GAC and BCR were 5.82, 5.86 and 5.72, respectively, which were higher than the appropriate $\mathrm{pH}(\mathrm{pH}=4.2)$. The reason for the higher $\mathrm{pH}$ is that the microorganisms in the activated sludge demonstrated low microbial activity and did not adapt to the anaerobic environment after being inoculated into the CMISR. However, the $\mathrm{pH}$ decreased gradually with the degradation of the organic matter and the accumulation of volatile acid, and on day 10, the pHs were 4.41 (ZMS), 4.53 (GAC), and 4.82 (BCR), respectively at the OLR of $12 \mathrm{~kg} \mathrm{COD} / \mathrm{m}^{3} / \mathrm{d}$, with the OLR raised to $24 \mathrm{~kg} \mathrm{COD} / \mathrm{m}^{3} / \mathrm{d}$, the average $\mathrm{pHs}$ of ZMS, GAC and BCR decreased to 4.20, 4.27 and 4.63, respectively. The optimum OLR for hydrogenogens was 


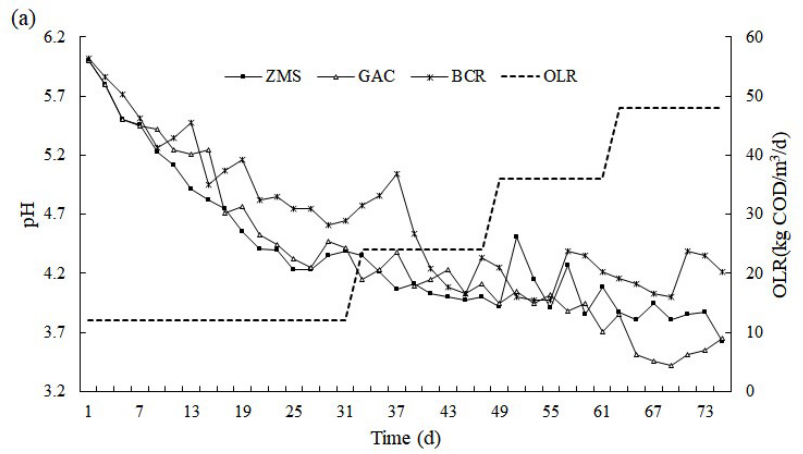

(b)

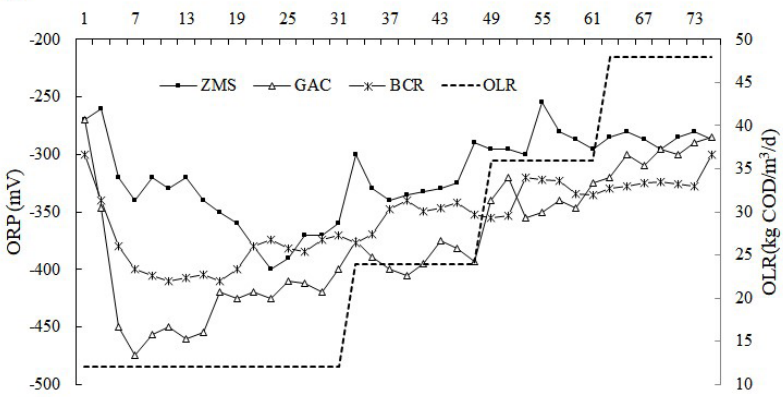

Fig. 6 The $\mathrm{pH}$ and ORP of immobilized CMISR system: (a) $\mathrm{pH}$, (b) ORP

$36 \mathrm{~kg} \mathrm{COD} / \mathrm{m}^{3} / \mathrm{d}$ according to the analyses between the OLR and HPR (Section 3.1), and at the same time, the pHs under this OLR were 4.07 (ZMS), 3.96 (GAC) and 4.17 $(\mathrm{BCR})$, respectively, which is the appropriate $\mathrm{pH}$ range for the hydrogenogens and ethanol-type fermentation. When the OLR was increased to $48 \mathrm{~kg} \mathrm{COD} / \mathrm{m}^{3} / \mathrm{d}$, volatile acids were produced and accumulated through the hydrolysis and fermentation phase in the CMISR, and that caused the $\mathrm{pH}$ continued to decrease and to 3.83 (ZMS), 3.57 (GAC), and 4.15 (BCR), respectively. And the relatively lower $\mathrm{pH}$ inhibited the activity of some essential

\section{References}

[1] Demirbas, A. "Progress and recent trends in biofuels", Progress in Energy and Combustion Science, 33(1), pp. 1-18, 2007. https://doi.org/10.1016/j.pecs.2006.06.001

[2] Levin, D. B., Pitt, L., Love, M. "Biohydrogen production: prospects and limitations to practical application", International Journal of Hydrogen Energy, 29(2), pp. 173-185, 2004. https://doi.org/10.1016/s0360-3199(03)00094-6

[3] Holladay, J. D., Hu, J., King, D. L., Wang, Y. "An overview of hydrogen production technologies", Catalysis Today, 139(4), pp. 244-260, 2009.

https://doi.org/10.1016/j.cattod.2008.08.039

[4] Zaidi, A. A., Feng, R. Z., Yue, S., Khan, S. Z., Mushtaq, K. "Nanoparticles augmentation on biogas yield from microalgal biomass anaerobic digestion", International Journal of Hydrogen Energy, 43(31), pp. 14202-14213, 2018.

https://doi.org/10.1016/j.ijhydene.2018.05.132 enzymes and metabolic pathways [41], which caused the decreasing of hydrogen production (Table 3).

The ORPs (Fig. 6 (b)) showed the CMISR was in a strictly anaerobic condition. At the first few days of the start-up, the ORPs were affected by the dissolved oxygen by intermittent aeration, and kept at -270 to $-300 \mathrm{mV}$. During the operation, the dissolved oxygen was consumed by microorganisms in the system.

\section{Conclusions}

With molasses used as the fermentation substrate, immobilized sludge biohydrogen production systems with ZMS, GAC and BCR as carrier materials were studied in CMISR system. Both the OLR and the carrier materials type affected biohydrogen productivity and operation stability. The maximum hydrogen production rate (HPR) of $2.86 \mathrm{~L} / \mathrm{L} / \mathrm{d}$ was obtained with $\mathrm{BCR}$ as the immobilized material under the OLR of $48 \mathrm{~kg} \mathrm{COD} / \mathrm{m}^{3} / \mathrm{d}$, and the maximum COD removal efficiency was $41.92 \%$ with substrate degradation rate of $44.88 \%$ under stable ethanol-type fermentation in CMISR. The results indicated that biological ceramic ring get better hydrogen production and wastewater treatment performance as sludge carrier material for hydrogen production in immobilized bioprocesses. The findings obtained from this study seem to be promising for the use of immobilized bioreactor configuration using biological ceramic ring as carrier material for enhanced biohydrogen production.

\section{Acknowledgements}

This project was funded by the Fundamental Research Funds for the Doctor (318/318051905) and the Fundamental Research Funds for the Central Universities (2572015AA17).

[5] Yazdani, S. S., Gonzalez, R. "Anaerobic fermentation of glycerol: a path to economic viability for the biofuels industry", Current Opinion in Biotechnology, 18(3), pp. 213-219, 2007. https://doi.org/10.1016/j.copbio.2007.05.002

[6] Noblecourt, A., Christophe, G., Larroche C., Fontanille, P. "Hydrogen production by dark fermentation from pre-fermented depackaging food wastes", Bioresource Technology, 247, pp. 864-870, 2018. https://doi.org/10.1016/j.biortech.2017.09.199

[7] Hou, Y. P., Peng, D. C., Wang, B. B., Zhang, X. Y., Xue, X. D. "Effects of stirring strategies on the sludge granulation in anaerobic CSTR reactor", Desalination and Water Treatment, 52(34-36), pp. 6348-6355, 2014. https://doi.org/10.1080/19443994.2013.841102 
[8] Nualsri, C., Kongjan, P., Reungsang, A. "Direct integration of CSTR-UASB reactors for two-stage hydrogen and methane production from sugarcane syrup", International Journal of Hydrogen Energy, 41(40), pp. 17884-17895, 2016.

https://doi.org/10.1016/j.ijhydene.2016.07.135

[9] Girault, R., Bridoux, G., Nauleau, F., Poullain, C., Buffet, J., Peu, P., Sadowski, A. G., Béline, F. "Anaerobic co-digestion of waste activated sludge and greasy sludge from flotation process: Batch versus CSTR experiments to investigate optimal design", Bioresource Technology, 105, pp. 1-8, 2012. https://doi.org/10.1016/j.biortech.2011.11.024

[10] Singh, L., Wahid, Z. A. "Methods for enhancing bio-hydrogen production from biological process: A review", Journal of Industrial and Engineering Chemistry, 21, pp. 70-80, 2015.

https://doi.org/10.1016/j.jiec.2014.05.035

[11] Elbeshbishy, E., Dhar, B. R., Nakhla, G., Lee, H. S. "A critical review on inhibition of dark biohydrogen fermentation", Renewable and Sustainable Energy Reviews, 79, pp. 656-668, 2017. https://doi.org/10.1016/j.rser.2017.05.075

[12] Lozinsky, V. I., Galaev, I. Y., Plieva, F. M., Savinal, I. N., Jungvid, H., Mattiasson, B. "Polymeric cryogels as promising materials of biotechnological interest", Trends in Biotechnology, 21(10), pp. 445-451, 2003. https://doi.org/10.1016/j.tibtech.2003.08.002

[13] Mudhoo, A., Torres-Mayanga, P. C., Forster-Carneiro, T., Sivagurunathan, P., Kumar, G., Komilis, D., Sanchez, A. "A review of research trends in the enhancement of biomass-to-hydrogen conversion", Waste Management, 79, pp. 580-594, 2018. https://doi.org/10.1016/j.wasman.2018.08.028

[14] Hassan, A. H. S., Mietzel, T., Brunstermann, R., Schmuck, S., Schoth, J., Küppers, M., Widmann, R. "Fermentative hydrogen production from low-value substrates", World Journal of Microbiology and Biotechnology, 34(12), Article number: 176, 2018. https://doi.org/10.1007/s11274-018-2558-9

[15] Lutpi, N. A., Jahim, J. M., Mumtaz, T., Harun, S., Abdul, P. M. "Batch and continuous thermophilic hydrogen fermentation of sucrose using anaerobic sludge from palm oil mill effluent via immobilisation technique", Process Biochemistry, 51(2), pp. 297-307, 2016.

https://doi.org/10.1016/j.procbio.2015.11.031

[16] Mohan, S. V., Mohanakrishna, G., Reddy, S. S., Raju, B. D., Rao, K. S. R., Sarma, P. N. "Self-immobilization of acidogenic mixed consortia on mesoporous material (SBA-15) and activated carbon to enhance fermentative hydrogen production", International Journal of Hydrogen Energy, 33(21), pp. 6133-6142, 2008. https://doi.org/10.1016/j.ijhydene.2008.07.096

[17] Kumar, N., Das, D. "Continuous hydrogen production by immobilized Enterobacter cloacae IIT-BT 08 using lignocellulosic materials as solid matrices", Enzyme and Microbial Technology, 29(4-5), pp. 280-287, 2001.

https://doi.org/10.1016/S0141-0229(01)00394-5

[18] Babel, S., Kurniawan, T. A. "Low-cost adsorbents for heavy metals uptake from contaminated water: a review", Journal of Hazardous Materials, 97(1-3), pp. 219-243, 2003.

https://doi.org/10.1016/s0304-3894(02)00263-7
[19] Rafatullah, M., Sulaiman, O., Hashim, R., Ahmad, A. "Adsorption of methylene blue on low-cost adsorbents: A review", Journal of Hazardous Materials, 177(1-3), pp. 70-80, 2010.

https://doi.org/10.1016/j.jhazmat.2009.12.047

[20] Casci, J. L. "Zeolite molecular sieves: preparation and scale-up", Microporous and Mesoporous Materials, 82(3), pp. 217-226, 2005. https://doi.org/10.1016/j.micromeso.2005.01.035

[21] Liu, Y. H., Li, X. P., Ji, R. J., Yu, L. L., Zhang, H. F., Li, Q. Y. "Effect of technological parameter on the process performance for electric discharge milling of insulating $\mathrm{Al}_{2} \mathrm{O}_{3}$ ceramic", Journal of Materials Processing Technology, 208(1-3), pp. 245-250, 2008. https://doi.org/10.1016/j.jmatprotec.2007.12.143

[22] Keskin, T., Giusti, L., Azbar, N. "Continuous biohydrogen production in immobilized biofilm system versus suspended cell culture", International Journal of Hydrogen Energy, 37(2), pp. 1418-1424, 2012. https://doi.org/10.1016/j.ijhydene.2011.10.013

[23] Keskin, T., Aksöyek, E., Azbar, N. "Comparative analysis of thermophilic immobilized biohydrogen production using packed materials of ceramic ring and pumice stone", International Journal of Hydrogen Energy, 36(23), pp. 15160-15167, 2011. https://doi.org/10.1016/j.ijhydene.2011.08.078

[24] Sun, C., Hao, P., Qin, B., Wang, B., Di, X., Li, Y. "Co-production of hydrogen and methane from herbal medicine wastewater by a combined UASB system with immobilized sludge $\left(\mathrm{H}_{2}\right.$ production) and UASB system with suspended sludge $\left(\mathrm{CH}_{4}\right.$ production)", Water Science \& Technology, 73(1), pp. 130-136, 2016.

https://doi.org/10.2166/wst.2015.471

[25] Gilcreas, F. W. "Standard methods for the examination of water and waste water", American Journal of Public Health and the Nation's Health, 56(3), pp. 387-388, 1966.

https://doi.org/10.2105/ajph.56.3.387

[26] Wu, S. Y., Hung, C. H., Lin, C. Y., Lin, P. J., Lee, K. S., Lin, C. N., Chang, F. Y., Chang, J. S. "HRT-dependent hydrogen production and bacterial community structure of mixed anaerobic microflora in suspended, granular and immobilized sludge systems using glucose as the carbon substrate", International Journal of Hydrogen Energy, 33(5), pp. 1542-1549, 2008. https://doi.org/10.1016/j.ijhydene.2007.10.020

[27] Zheng, H., Zeng, R. J., Angelidaki, I. "Biohydrogen production from glucose in upflow biofilm reactors with plastic carriers under extreme thermophilic conditions $\left(70^{\circ} \mathrm{C}\right) "$, Biotechnology and Bioengineering, 100(5), pp. 1034-1038, 2008.

https://doi.org/10.1002/bit.21826

[28] Li, Q. Y., Lv, Y. H., Ding, R., Wang, L. N., Ren, N. Q., Wei, L., Li, Y. F. "Hydrogen production efficiency and microbial community of ethanol-type fermentation", Journal of Renewable and Sustainable Energy, 11(1), Article number: 013105, 2019. https://doi.org/10.1063/1.5024723

[29] Yun, J. H. Cho, K. S. "Effect of hydraulic retention time on suppression of methanogens during a continuous biohydrogen production process using molasses wastewater", Journal of Environmental Science and Health Part A: Toxic/Hazardous Substances and Environmental Engineering, 52(1), pp. 37-44, 2017. https://doi.org/10.1080/10934529.2016.1221221 
[30] Puyol, D., Batstone, D. J., Hulsen, T., Astals, S., Peces, M., Kromer, J. O. "Resource Recovery from Wastewater by Biological Technologies: Opportunities, Challenges, and Prospects", Frontiers in Microbiology, 7, Article number: 2106, 2017. https://doi.org/10.3389/fmicb.2016.02106

[31] Feng, R. Z., Zaidi, A. A., Zhang, K., Shi, Y. "Optimisation of Microwave Pretreatment for Biogas Enhancement through Anaerobic Digestion of Microalgal Biomass", Periodica Polytechnica Chemical Engineering, 63(1), pp. 65-72, 2019. https://doi.org/10.3311/PPch.12334

[32] Zhang, S.. Liu, M., Chen, Y., Pan, Y. T. "Achieving ethanol-type fermentation for hydrogen production in a granular sludge system by aeration", Bioresource Technology, 224, pp. 349-357, 2017. https://doi.org/10.1016/j.biortech.2016.11.096

[33] Ren, N. Q., Chua, H., Chan, S. Y., Tsang, Y. F., Wang, Y. J., Sin, N. "Assessing optimal fermentation type for bio-hydrogen production in continuous-flow acidogenic reactors", Bioresource Technology, 98(9), pp. 1774-1780, 2007.

https://doi.org/10.1016/j.biortech.2006.07.026

[34] Kumar, G., Mudhoo, A., Sivagurunathan, P., Nagarajan, D., Ghimire, A., Lay, C. H., Lin, C. Y., Lee, D. J., Chang, J. S. "Recent insights into the cell immobilization technology applied for dark fermentative hydrogen production", Bioresource Technology, 219, pp. 725-737, 2016. https://doi.org/10.1016/j.biortech.2016.08.065

[35] Chu, Y. B., Wei, Y. L., Yuan, X. Z., Shi, X. S. "Bioconversion of wheat stalk to hydrogen by dark fermentation: Effect of different mixed microflora on hydrogen yield and cellulose solubilisation", Bioresource Technology, 102(4), pp. 3805-3809, 2011. https://doi.org/10.1016/j.biortech.2010.11.092
[36] Jamali, N. S., Jahim, J. M., Isahak, W. N. R. W. "Biofilm formation on granular activated carbon in xylose and glucose mixture for thermophilic biohydrogen production", International Journal of Hydrogen Energy, 41(46), pp. 21617-21627, 2016. https://doi.org/10.1016/j.ijhydene.2016.05.092

[37] Afridi, Z. U. R., Wu, J., Li, Z. H., Akand, R., Cao, Z. P., Poncin, S., Li, H. Z. "Novel insight of spatial mass transfer conditions of upflow anaerobic reactor", Journal of Cleaner Production, 204, pp. 390-398, 2018.

https://doi.org/10.1016/j.jclepro.2018.09.022

[38] Vasmara, C., Pindo, M., Micheletti, D., Marchetti, R. "Initial pH influences microbial communities composition in dark fermentation of scotta permeate", International Journal of Hydrogen Energy, 43(18), pp. 8707-8717, 2018.

https://doi.org/10.1016/j.ijhydene.2018.03.122

[39] Liu, C., Luo, G., Wang, W., He, Y. F., Zhang, R. H., Liu, G. Q. "The effects of $\mathrm{pH}$ and temperature on the acetate production and microbial community compositions by syngas fermentation", Fuel, 224, pp. 537-544, 2018. https://doi.org/10.1016/j.fuel.2018.03.125

[40] Zheng, M. X., Zheng, M. Y., Wu, Y. Y., Ma, H. L., Wang, K. J. "Effect of $\mathrm{pH}$ on types of acidogenic fermentation of fruit and vegetable wastes", Biotechnology and Bioprocess Engineering, 20(2), pp. 298-303, 2015. https://doi.org/10.1007/s12257-014-0651-y

[41] Infantes, D., del Campo, G., Villasenor, J., Fernandez, F. J. "Kinetic model and study of the influence of $\mathrm{pH}$, temperature and undissociated acids on acidogenic fermentation", Biochemical Engineering Journal, 66, pp. 66-72, 2012. https://doi.org/10.1016/j.bej.2012.04.017 